\title{
Quantitative Analysis, Distribution and Traditional Management of Pigeon Pea [Cajanus Cajan (L.) Millsp.] Landraces' Diversity in Southern Benin
}

\author{
Zavinon Fiacre, Msc. \\ Adoukonou-Sagbadja Hubert, PhD \\ University of Abomey-Calavi, \\ Laboratory of Genetic Resources and Molecular Breeding, Benin \\ Ahoton Léonard, PhD \\ University of Abomey-Calavi, Department of Plant Production, \\ Faculty of Agronomic Sciences, Benin \\ Vodouhê Raymond, PhD \\ Bioversity International, Office of West and Central Africa, Benin \\ Ahanhanzo Corneille, PhD \\ University of Abomey-Calavi, \\ Laboratory of Plant Biotechnology and Breeding, Benin
}

Doi: 10.19044/esj.2018.v14n9p184 URL:http://dx.doi.org/10.19044/esj.2018.v14n9p184

Abstract

Pigeon pea (Cajanus cajan (L.) Millsp.) is an important drought tolerant legume cultivated in the semi-arid regions, mainly in Sub-Saharan Africa. Despites its important potential, the crop is neglected and underutilized in many countries including Benin. In order to develop efficient in-situ strategies conservation, a study was conducted to quantify pigeon pea landrace diversity and access its spatial distribution and traditional management by local communities in southern Benin. Therefore, an ethnobotanical survey was conducted in 20 producing villages in southern Benin. Altogether, 26 farmernamed landraces further grouped into five categories were recorded with the number of landraces really cultivated per farmer comparably lower than that listed. Besides, two landraces' categories were found to be common in the study area while two other were found highly threatened. Diverse parameters such as varietal richness, Shannon-Weaver Diversity Index, Simpson index and Pielou's evenness were used to quantify pigeon pea diversity that appeared to be unequally distributed through the different agro-ecologies and villages surveyed. The study confirmed the absence of correlations between farmers' gender and landrace diversity which was nonetheless found to be significantly shaped by the ethnic group and the field size exploited by farmers 
$(P<0.05)$. In diversity management, five preference criteria with variable importance across the ethnic groups were used by farmers of which cooking time and market value appeared to be the most important. Exhaustive germplasm collections, morphological/molecular characterizations of these landraces are required for efficient conservation of this important but neglected crop genetic resource in Benin.

Keywords: Pigeon pea - Landrace diversity - Diversity index - Benin - Insitu conservation

\section{Introduction}

Agro-biodiversity includes the diversity of cultivated plants relevant for food and agriculture (Pascual et al., 2011). It is always the basis for human food production systems (Brush, 2004) and provides valuable ecosystem services and functions for agricultural production (Dury et al., 2011). Numerous studies highlighted the role of agro-biodiversity in providing enhanced nutrition (Yenagi et al., 2010, Pascual et al., 2011), environmental benefits (Perrings et al., 2006, Jackson et al., 2007), improved livelihoods for small-scale farmers (Keatinge et al., 2009, Jackson et al., 2010) and increased resilience to climate change (Padulosi et al., 2011, Ortiz 2011a; Guarino and Lobell 2011). However, serious threats nowadays hamper the agrobiodiversity worldwide, particularly in remote areas where many important but minor crops and species commonly grown by poor farmers are neglected or abandoned. The consequence of this threat is the erosion of the genetic resources of these neglected and underutilized crops as they are replaced by improved cultivars or cash crops (Adoukonou-Sagbadja et al., 2006). However, these crops and species have great untapped potential to support smallholder farmers and rural communities by improving their incomes, food and nutritional security while also sustaining the genetic resources needed to address present and future environmental challenges (Kahane et al., 2013). It is therefore necessary to develop efficient strategies in the conservation and valorization of these minor crops and species (IPAGRI 2002, Gruère et al., 2009). Among these minor but valuable species, there is pigeon pea (Cajanus cajan (L.) Millsp.), an important legume of the tropics, sub-tropics and warmer regions of the world.

Pigeon pea belongs to the genus Cajanus under Fabaceae family. The genus Cajanus comprises 32 species, most of which are found in India and Australia although one is native to West Africa. Pigeon pea is the only cultivated food crop of the Cajaninae sub-tribe and has a diploid genome with 11 pairs of chromosomes $(2 \mathrm{n}=2 \mathrm{x}=22)$ (Greilhuber and Obermayer 1998). It is grown for several purposes including food security, income generation, livestock feed and in agroforestry (Seleman et al., 2016). Pigeon pea is rich in 
seed protein (20 - 22\%) and constitutes a major supplement in the diets of most vegetarian families around the globe (Saxena et al., 2012). The leaves are used in the treatment of some skin infections (Sharma et al., 2011). It has also been documented that in several countries, home remedies are produced from processing pigeon pea leaves to treat respiratory diseases such as bronchitis and pneumonia (Saxena et al., 2012). The extensive and deep root system of pigeon pea fixes atmospheric nitrogen and improves the quality and structure of soils (Sharma et al., 2011).

In Benin, pigeon pea is also unfortunately neglected. The national production of pigeon pea is ensured by a minority of small farmers on relatively reduced areas. The species is considered as a secondary crop and is not subject of high transaction while contributing to the population food security. Its production is therefore very low averaging 4436.9 tons per year. The neglected status of pigeon pea affects its varietal diversity and many pigeon pea landraces are threatened to disappear or are lost. Recently, the national agricultural program study defined pigeon pea as one of the nineteen neglected and underutilized priority crop species that merit attention and support (Dansi et al., 2012). In order to integrate its conservation and valorization in the strategies of increasing agricultural production in Benin, it is necessary to understand the current status and distribution of pigeon pea genetic diversity maintained in situ by the farmers.

In situ crop diversity results from interactions between many parameters such as biological, climatic, ecological and sociological factors (Labeyrie et al., 2013). However, social factors have been largely neglected in diversity studies (Leclerc et al., 2012). These factors have and continue to play an important role in the evolution and the distribution of crop diversity in situ. Indeed, the social relationships favor the diffusion of planting material, cultivation practices and traditional knowledge between farmers and can be also the barriers which limit both seed exchanges and the transmission of knowledge and practices between farmers' communities (Labeyrie et al., 2013, Diwakar et al., 2015). The importance of these factors were also highlighted in several ethnobotanical studies on other crops such as maize (Zea mays L.) in Ivory Coast (N'da et al., 2013), sorghum (Sorghum bicolor L. Moench) in Benin (Missihoun et al., 2012) or fonio millet (Digitaria exilis Stapf, D. iburua Stapf) in Togo (Adoukonou-Sagbadja et al., 2006).

Pigeon pea cultivation is mainly concentrated in the south and central parts of Benin, here designed as southern Benin. Recently, Ayena et al. (2017) conducted a study on farmers' knowledge in the use of pigeon pea diversity in Benin.The present study aimed to quantify the pigeon pea landrace diversity and assess its spatial distribution in situ and the traditional management of the genetic resources of this important but neglected crop in southern Benin. Besides, by completing that of Ayena et al. (2017), the study additionally re- 
evaluated the effects of social organization on landrace diversity and analyzes farmers' preference criteria in selecting, adopting or using pigeon pea landraces.

\section{Material and Methods \\ Description of the study area}

The study was conducted in the southern Benin (West Africa) between latitudes $6^{\circ} 10 \mathrm{~N}$ and $12^{\circ} 25 \mathrm{~N}$ and longitudes $0^{\circ} 45 \mathrm{E}$ and $3{ }^{\circ} 55 \mathrm{E}$ (Adam and Boko, 1993). The climate in southern Benin is of subequatorial type. This region has a relatively humid agro-ecology with two rainy seasons and a mean annual rainfall varying from $1100 \mathrm{~mm}$ to $1400 \mathrm{~mm} / \mathrm{year}$ (Yabi and Afouda, 2012). Mean annual temperatures range from 26 to $28^{\circ} \mathrm{C}$. The region has semideciduous forests or woodland and savannah woodland (Akoegninou et al., 2006, Houehanou et al., 2011). Pigeon pea was highly cultivated in the study area that covers three (03) agro-ecological zones (INSAE, 2015)

\section{Sites selection and sampling strategy}

Based on preliminary investigation, three agro-ecological zones were considered for survey. These are the agro-ecological zone $\mathrm{V}$ namely known as "Cotton zone in center of Benin", the agro-ecological zone VI or "Bar land zone" and the agro-ecological zone VII or "Zone of depression". Twenty (20) villages belonging to five administrative districts were randomly selected through the three agro-ecologies (Figure 1; Table 1). The main criteria used to select villages were effective pigeon pea production and easy accessibility to the village. In each village, 10 to 20 farmers were randomly selected for individual interviews. Pigeon pea producers interviewed are those who had at least one pigeon pea field during the survey. In total, 293 farmers belonging to five ethnic groups (Adja, Agoun, Fon, Holli and Nago) were surveyed in the study area. 


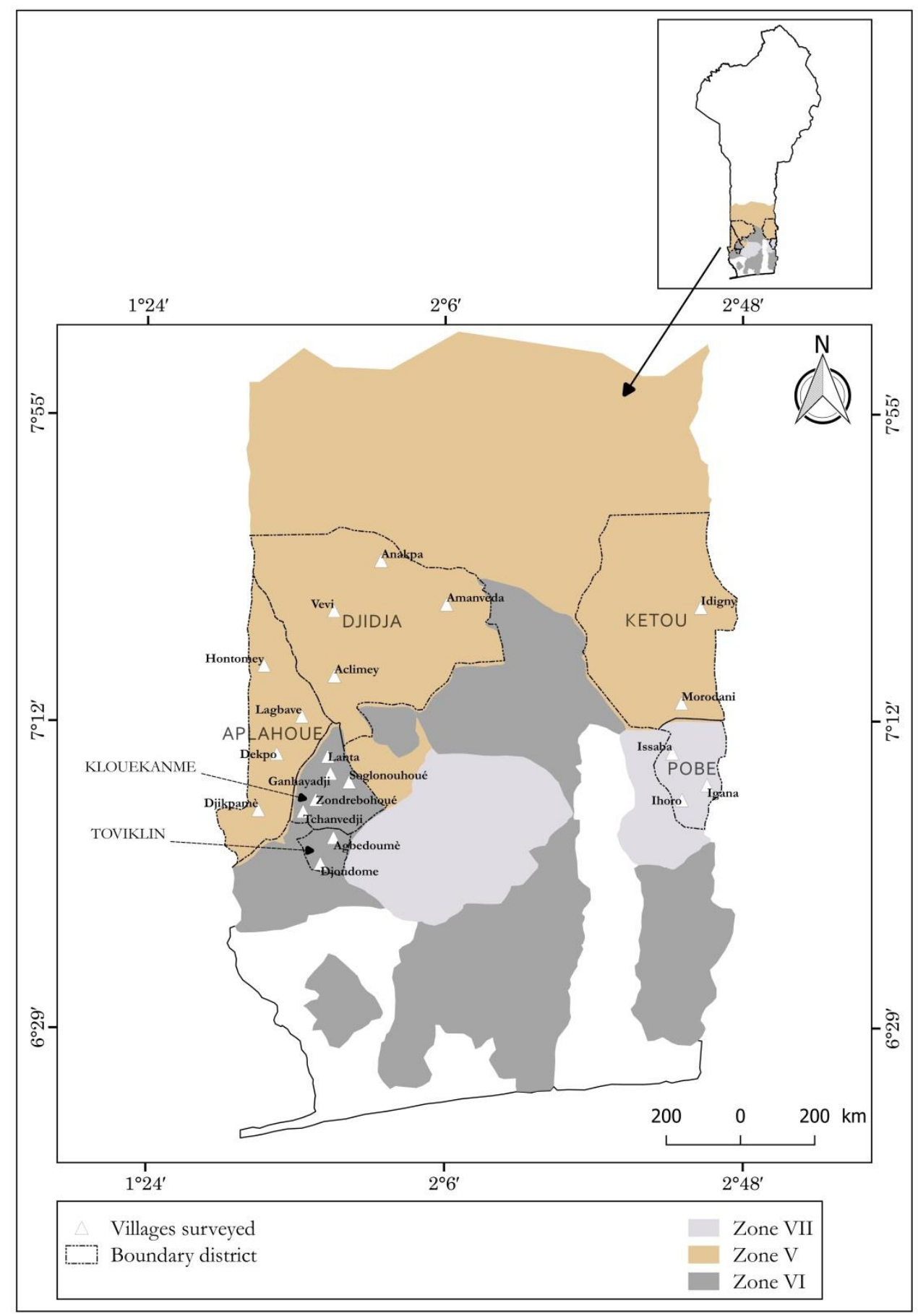

Figure 1: Map of the study area showing agro-ecological zones and villages surveyed in southern Benin 
Table 1: Distribution and location characteristics of the villages surveyed during the study

\begin{tabular}{lllll}
\hline $\mathrm{N}^{\text {o }}$ & Villages & Districts & Agro-ecological zones & Ethnic groups \\
\hline 1 & Anakpa & Djidja & Zone V & Fon \\
2 & Aclimey & Djidja & Zone V & Agoun, Fon \\
3 & Vevi & Djidja & Zone V & Agoun, Fon \\
4 & Amanveda & Djidja & Zone V & Fon \\
5 & Morodani & Kétou & Zone V & Holli \\
6 & Idigny & Kétou & Zone V & Nago \\
7 & Djikpamè & Aplahoué & Zone V & Adja \\
8 & Dekpo & Aplahoué & Zone V & Adja \\
9 & Hontomey & Aplahoué & Zone V & Adja \\
10 & Lagbave & Aplahoué & Zone V & Adja \\
11 & Agbedoumè & Toviklin & Zone VI & Adja \\
12 & Djoudomè & Toviklin & Zone VI & Adja \\
13 & Zondrebohoué & Klouékanmè & Zone VI & Adja \\
14 & Ganhayadji & Klouékanmè & Zone VI & Adja \\
15 & Soglonouhoué & Klouékanmè & Zone VI & Adja \\
16 & Lanta & Klouékanmè & Zone VI & Adja \\
17 & Tchanvedji & Klouékanmè & Zone VI & Adja \\
18 & Iganan & Pobè & Zone VII & Holli, Nago \\
19 & Ihoro & Pobè & Zone VII & Holli, Nago \\
20 & Issaba & Pobè & Zone VII & Holli \\
\hline
\end{tabular}

\section{Ethnobotanical survey and data collection}

For better data collection, informal conversations were first conducted with 30 farmers through the study area with the objective to harmonize information categories to be collected. Based on the information gathered from these farmers, the ethnobotanical survey was then made in households from August to October 2015. Data were collected from the different villages through the application of Participatory Research Appraisal tools and techniques such as individual and group interviews and field visits using a questionnaire as recommended by Adoukonou-Sagbadja et al. (2006) and latter applied by Kombo et al. (2012) and Assogba et al. (2015). During the surveys, semi-structured questionnaires were administered and the interviews were conducted with the help of translators recruited in each sociolinguistic group surveyed. In each village, traditional chiefs and local authorities were involved in the study to facilitate the meetings and data collection.

The interviews were conducted in four sections. The first section, related to the sociocultural information of the farmers, concerned their age, 
sex and the ethnic groups they belonged to. The second section dealt with varietal diversity. In this section, it was question to record all the diversity known or cultivated by the farmers. First, we asked the farmers to inventory all the pigeon pea landraces they knew and then to list those they were growing and the devoted areas (in hectare) for the cropping season 2015. Pigeon pea landrace designed the varietal diversity which the farmers can clearly distinguish on the basis of agro-morphological traits, phenological attributes, postharvest characteristics and differential adaptive performances under biotic and abiotic stresses. To avoid bias, and taking as basis the previous work by Ayena et al. (2017) on pigeon pea in the study area, correspondences between landrace names given in diverse languages were made to define landrace category following their described characteristics and name signification. Besides, for easier convenience, Adja sociolinguistic group names were here used as reference in this study to design landrace category. The third section reported the inventory of farmers' preference criteria used to select the local varieties. Finally, the last section of the survey was devoted to the modes of management of landraces and acquisition of planting seeds. In order to facilitate the analysis, we described the overall diversity of pigeon pea landraces by village, ethnic group, sex, age and categories of fields' size. To this end, ethnobotanical data were used to assign farmers to one of five ethnic groups identified and informants were also classified into one of four age groups $(\leq 35,35-60$, and $>60$ years old) (Dansi et al., 2010) Three fields' size categories were constituted at priori for ease of analysis ( $\leq 0.5 \mathrm{ha}, 0.5-1$ ha, and $>1$ ha) (Labeyrie et al., 2013). Finally, additional surveys were later conducted through the year 2016 in Beninese agricultural research centers in order to gather information about the current status of pigeon pea production in the country.

\section{Data analysis}

Data were analyzed through descriptive statistics (frequencies, percentages, means, etc.) to generate summaries and tables at different levels (zone, villages, individuals, etc.). To test the effect of each of the four social factors which affected the pigeon pea landrace diversity, diverse statistical analyses were performed. Indeed, a varietal richness was first used as a proxy for diversity in different social groups. The distribution of the diversity was assessed by a calculation of three diversity index. Multivariate statistical analysis (Principal component analysis and correspondence analysis) was further performed to access the relationships between farmers' criteria and ethnic group in one hand and the link between farmers' criteria and the landraces cultivated in the second hand. All analyses were carried out with the R software package vs. 2.13.0 (R Development Core Team, 2014). 
The varietal diversity analysis in the study area was performed using the varietal richness following the methodology described by Labeyrie et al. (2013). It is the number of pigeon pea landrace categories inventoried in each household. Varietal richness known $(S=$ number of pigeon pea landrace category cited by farmers) and varietal richness planted ( $S v=$ number of pigeon pea landrace category grown for 2015 season) were recorded. The mean and cumulative richness were calculated at village and agro-ecological zone levels for comparison. The extent of each landrace was assessed in order to identify which landrace categories were rare, abundant or highly cultivated and which landrace categories were recently introduced in the study area. The frequency of citations and the area devoted for each landrace were used to generate a diagram. The relationships between diversity of pigeon pea landraces and social factors was assessed using generalized linear models with Poisson error structure and analysis of variance which are adequate for quantitative data analysis. The effects of social factors on the number of landrace categories known as well on the number of pigeon pea landraces practiced by farmers during 2015 season were also tested.

For diversity distribution analysis, the spatial distribution of the varietal diversity was assessed at village and agro-ecological levels in order to compare the variation within them. The frequency estimation of individual landrace and the area devoted for each landrace was used to calculate three different diversity indexes, i.e. Shannon-Weaver Diversity Index, Simpson index and Pielou's evenness index.

The Shannon-Weaver Diversity Index $\left(H^{\prime}\right)$ is one of the simplest and most basically used as diversity indices. It can express the diversity within the community and is generally used to compare the diversity of landraces (Adoukonou-Sagbadja et al., 2007). But Shannon-Weaver Diversity cannot explain whether the species or landrace is abundant or not. However, the diversity of the particular location will be higher if the species or landrace is equally distributed or abundant. $H^{\prime}$ values were calculated for the village landraces using the following equation (Shannon and Weaver, 1963):

$$
H^{\prime}=-\sum_{1}^{S v} P i \log _{2} P i
$$

where, 'Pi' $=$ proportion numbers of $i^{\text {th }}$ landrace i.e., $\mathrm{Pi}=\mathrm{Si} / \Sigma \mathrm{Si}$, with 'Si' the area devoted to ith landrace. 'S $v$ ' is the total number of landraces.

$H^{\prime}$ is maximum when all landraces are represented in the village. Shannon-Weaver Diversity Index is null $\left(H^{\prime}=0\right)$ if there is only one landrace was cultivated in the community.

Simpson index $(D)$ has also been calculated. It measured the dominance of the landrace at a particular community level and gives the measurement on whether the community is dominated by few landraces or not. 
But it lacks the information on which the species is dominant in the community. $D$ was calculated as described by Simpson (1949) following the formula:

$$
D=1-\sum_{1}^{S v} P i^{2}
$$

The index (Simpson index) measures dominance on a ' 0 to 1 ' scale. If only one landrace is present in the community $\mathrm{D}=0$. $\mathrm{D}$ will be maximum when the number of landraces in the community is important.

The equal abundance of the species or landrace in a village is commonly measured through evenness index. Here, Pielou's evenness index $(E)$ was used to describe the diversity in term of landrace evenness, i.e., how equally abundant the landrace was within the villages. $E$ was calculated as indicated by Pielou (1966) following the formula:

$$
E=\frac{H^{\prime}}{\log _{2} S v}
$$

Evenness values can range between 0 and 1: a value of 0 corresponds to a community of one species or one landrace (total dominance or no diversity), and a value of 1 to a community where all species or landraces are equally abundant.

Farmers' preference criteria used to select landraces within each ethnic group were analyzed using multivariate analysis approaches. Indeed, a principal component analysis (PCA) was performed to understand the relationships between farmers' preference criteria and ethnic groups. The average score of each criterion was calculated and a data matrix (ethnic groups and criteria) was constructed to perform the PCA. A factorial analysis of correspondence (FAC) was further performed to understand the link between farmers' preference criteria and the pigeon pea landraces recorded in the study area.

\section{Results}

\section{Current status of pigeon pea production in Benin}

Pigeon pea is mainly produced in the southern part of Benin. The administrative districts such as Savè, Savalou, Ouèssè, Kétou, Djidja, Aplahoué and Dassa in the agro-ecological zone V; Klouékanmey district in the agro-ecological zone VI and Pobè district in the agro-ecological zone VII are the main areas of pigeon pea production in Benin. The national production has never reached 10,000 tons and its production was erratic during these last five years considering the total area cultivated. On average, the total area cultivated the last few years was 3295.2 ha. Pigeon pea production recorded a slight increase in 2015 when it reached 4436.9 ha. 
The information gathered during this study confirmed the drop in pigeon pea production and its neglected status in Benin. Indeed, pigeon pea cultivation was only at household level and essentially done by poor farmers generally on small surfaces. In the study area, pigeon pea cultivation was more practiced by the women than men who devoted their selves to the cultivation of other crops that can mostly profit them such as tomato or cassava in Adja ethnic group, or maize in Holli and Nago sociolinguistic groups. The fundamental reason of pigeon pea abandon advocated by farmers was the long vegetative cycle of the plant. The varieties grown by farmers had a long cycle, until 12 months or more. Therefore, it was not possible for the producers to exploit the land for other crops when they produced pigeon pea. For example, in Adja socio-linguistic group, farmers have many difficulties to get the land. In such conditions, they exploited rationally the lands for producing many crops a year. In addition, the drop of pigeon pea production was also due to its low demand on the market. Therefore, the farmers who continued to cultivate pigeon pea did it for their self-consumption and other important characteristics of the plant such as soil fertilization and traditional weeds control.

\section{Pigeon pea landrace diversity, its extent and importance in the study area}

Pigeon pea is locally known as Klouékoun in Fon sociolinguistic group, Otinin in Nago and Holli sociolinguistic groups and Eklui in Adja sociolinguistic group. Apart from this diversity in common name related to the sociolinguistic diversity of farmers in the study area, the pigeon pea producers used many other criteria for distinguishing local varieties. Local names recorded derived from agronomic or morphologic attributes, culinary characteristics or the origin of local varieties. In general, the seed color (Fig. 2) was usually the main criterion used by farmers for distinguishing the local varieties. Based on this criterion, more than twenty-five local names were recorded. The other criteria secondary used by farmers are the plant cycle, seed size, grain yield, organoleptic characteristics such as cooking duration, taste, etc. By using correspondence analysis between names, a total of seven different pigeon pea landrace categories could be distinguished. The table 2 summaries the local names of pigeon pea landraces after correspondence analysis between them using Adja sociolinguistic group as reference. 
Table 2: Local names of pigeon pea landraces and their characteristics

\begin{tabular}{|c|c|c|c|}
\hline $\mathbf{N}^{\circ}$ & $\begin{array}{c}\text { Landrace' } \\
\text { category } \\
\text { name }\end{array}$ & Other names (ethnic group) & Seed and other plant characteristics \\
\hline 1 & Projetklui & $\begin{array}{c}\text { Klouekoun wlanwlan (Fon), } \\
\text { Adjaissa (Adja) }\end{array}$ & Multicolored seeds, early maturing landrace \\
\hline 2 & Ekluidjoun & $\begin{array}{c}\text { Otinin Kpoukpa (Nago, } \\
\text { Holli), Klouekoun vovo (Fon) }\end{array}$ & Red and small seeds \\
\hline 3 & Kpédévi & $\begin{array}{c}\text { Egblèzin (Adja) Adjaton } \\
\text { (Fon) Otinin cader (Fon Holli) }\end{array}$ & Brown seeds, produce two time a year \\
\hline 4 & Wletchivé & Caderklui (Adja) & Dark brown seeds, very short cooking time \\
\hline 5 & Tchidjahou & $\begin{array}{c}\text { Ekluigbali, Gbakeli, Hodja } \\
\text { (Adja), Klouekoun wewe, } \\
\text { Kloue (Fon), Otinin foufou } \\
\text { (Nago, Holli) }\end{array}$ & White grains, big tree and late maturing \\
landrace
\end{tabular}

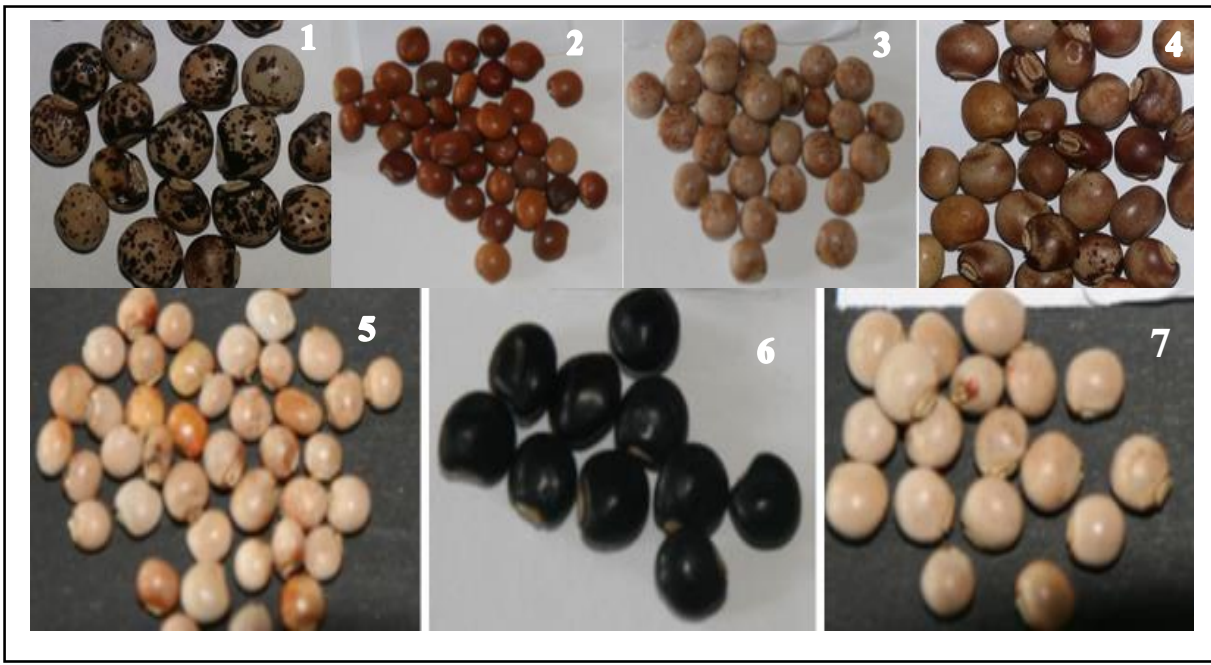

Figure 2: Illustration of seed colour variability in the different pigeon pea landrace categories grown in southern Benin.

In the study area, the number of landraces categories known or cited by farmer varied significantly across villages and agro-ecological zones (Table 3). In contrast, the number of landraces cultivated or really practiced by farmer was found to vary significantly only across villages. In general, the number of landraces really cultivated per farmer was very low comparably to that known or listed. It ranged an average from $1.07 \pm 0.26$ to $1.70 \pm 0.82$ landraces. The highest number of landraces cultivated per farmer was 
observed in the villages Agbedoumè and Ganhayadji and the lowest was found in Amanvèda and Vévi villages.

Table 3: Pigeon pea landraces' diversity known (cited) or cultivated per farmer at village and agro-ecological levels

\begin{tabular}{lccc}
\hline \multicolumn{1}{c}{$\begin{array}{c}\text { Study Zones and } \\
\text { villages }\end{array}$} & $\begin{array}{c}\text { Total number } \\
\text { of landraces } \\
\text { inventoried }\end{array}$ & $\begin{array}{c}\text { Number of } \\
\text { landraces } \\
\text { known/farmer }\end{array}$ & $\begin{array}{c}\text { Number of landraces } \\
\text { cultivated/farmer }\end{array}$ \\
\hline & & \multicolumn{2}{c}{ Agro-ecological Zones } \\
\hline Zone V & 7 & $3.58 \pm 1.38^{\mathrm{a}}$ & $1.23 \pm 0.50^{\mathrm{a}}$ \\
Zone VI & 5 & $3.20 \pm 0.82^{\mathrm{b}}$ & $1.38 \pm 0.76^{\mathrm{a}}$ \\
Zone VII & 4 & $2.24 \pm 0.70^{\mathrm{c}}$ & $1.33 \pm 0.50^{\mathrm{a}}$ \\
\hline & & & Villages \\
\hline Aclimey & 6 & $4.67 \pm 0.82^{\mathrm{a}}$ & $1.27 \pm 0.46^{\mathrm{d}}$ \\
Agbédoumè & 5 & $3.58 \pm 0.90^{\mathrm{b}}$ & $1.67 \pm 1.15^{\mathrm{b}}$ \\
Amanvèda & 6 & $3.20 \pm 1.61^{\mathrm{i}}$ & $1.07 \pm 0.26^{\mathrm{g}}$ \\
Anakpa & 6 & $4.47 \pm 1.25^{\mathrm{c}}$ & $1.53 \pm 0.74^{\mathrm{c}}$ \\
Dékpo & 4 & $2.90 \pm 0.57^{\mathrm{d}}$ & $1.20 \pm 0.42^{\mathrm{f}}$ \\
Djikpamè & 4 & $2.50 \pm 0.90^{\mathrm{f}}$ & $1.42 \pm 0.51^{\mathrm{d}}$ \\
Djoudomè & 4 & $3.00 \pm 0.94^{\mathrm{d}}$ & $1.40 \pm 0.97^{\mathrm{d}}$ \\
Ganhayadji & 4 & $3.60 \pm 0.70^{\mathrm{b}}$ & $1.70 \pm 0.82^{\mathrm{a}}$ \\
Hontonmey & 4 & $3.00 \pm 0.76^{\mathrm{d}}$ & $1.20 \pm 0.41^{\mathrm{e}}$ \\
Idigny & 4 & $2.67 \pm 0.65^{\mathrm{e}}$ & $1.25 \pm 0.45^{\mathrm{d}}$ \\
Iganan & 3 & $1.97 \pm 0.40^{\mathrm{g}}$ & $1.28 \pm 0.52$ \\
Ihoro & 2 & $1.86 \pm 0.35^{\mathrm{h}}$ & $1.36 \pm 0.49^{\mathrm{d}}$ \\
Issaba & 4 & $3.17 \pm 0.62^{\mathrm{i}}$ & $1.39 \pm 0.50^{\mathrm{d}}$ \\
Lagbavé & 7 & $3.60 \pm 1.35^{\mathrm{b}}$ & $1.27 \pm 0.46^{\mathrm{d}}$ \\
Lanta & 4 & $2.90 \pm 0.88^{\mathrm{d}}$ & $1.10 \pm 0.32^{\mathrm{g}}$ \\
Morodani & 4 & $3.00 \pm 0.91^{\mathrm{d}}$ & $1.11 \pm 0.47^{\mathrm{g}}$ \\
Soglonouhoue & 4 & $2.91 \pm 0.83^{\mathrm{d}}$ & $1.27 \pm 0.47^{\mathrm{d}}$ \\
Tchanvèdji & 4 & $3.08 \pm 0.67^{\mathrm{d}}$ & $1.25 \pm 0.62^{\mathrm{d}}$ \\
Vévi & 7 & $5.27 \pm 1.22^{\mathrm{j}}$ & $1.07 \pm 0.59^{\mathrm{d}}$ \\
Zondrèbohouè & $3.29 \pm 0.73^{\mathrm{i}}$ & $1.29 \pm 0.61^{\mathrm{d}}$ \\
\hline Landrae mean & 4 & 3 & \\
\hline
\end{tabular}

Landrace mean values in the same column followed with different letter differ significantly

By considering the ratio between frequency of citations and frequency of cultivation, the seven pigeon pea landrace categories recorded in the study area could be ranged into three groups (Fig. 3). The first group includes the pigeon pea landraces Tchidjahou and Djidjaklui with high ratio value (> 50\%). These two local varieties were well known and widely cultivated by many producers on large areas in their fields. They constituted the group of major landraces in the study zone. The second group is composed of three varieties (Kpédévi, Projetklui and Wlecthivé), displaying a ratio varying from $25 \%$ to $41 \%$. It is the group of newly emergent varieties introduced in the study area and the planting seed is not available to all producers. These were not yet very known but they were cultivated more or less on large extent by farmers. The last group was composed of Ekluidjoun and Ekluiyou landraces with very low 
ratio value. In general, many producers knew these landraces but their cultivation was limited or negligible. It is the group of threatened varieties.

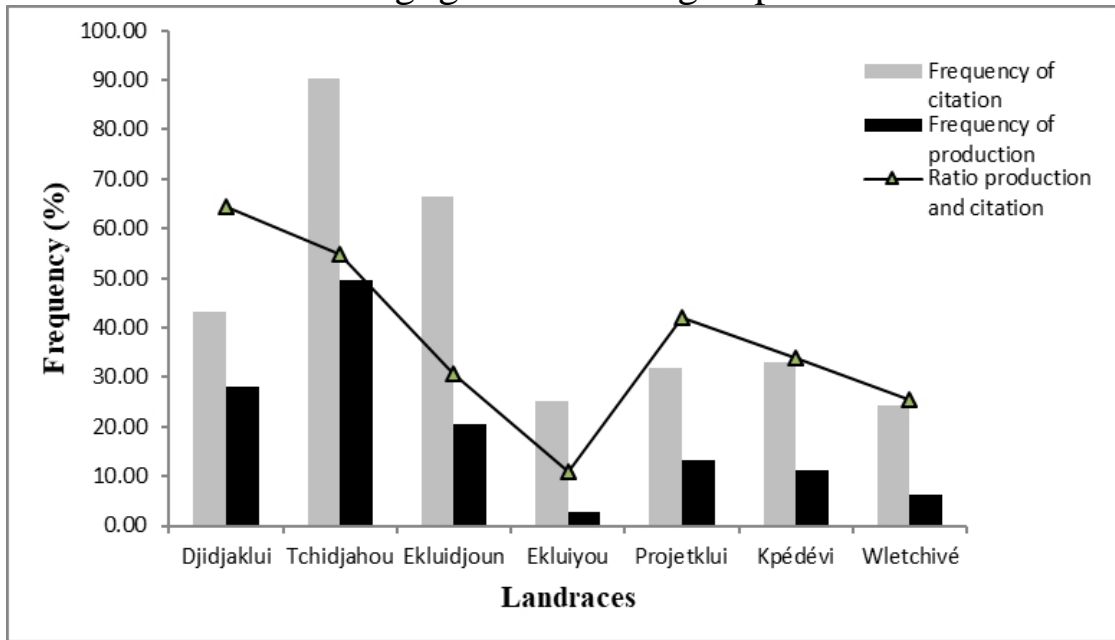

Figure 3: Extent and importance of pigeon pea landraces in Southern Benin

\section{Diversity index and spatial distribution of pigeon pea landraces}

The table 4 summarizes the diversity indexes and the varietal richness calculated at agro-ecological and village levels in the study zone. The results indicated that the pigeon pea varietal diversity was unequally distributed through the study zone. Indeed, at agro-ecological level, Shannon diversity index ranged from 1.42 to 2.33 while Pielou's Evenness ranged from 0.71 to 0.83 . The highest values of Shannon diversity index were observed in agroecological zones V and VI. All the seven (7) landrace categories inventoried were found in these zones which appeared therefore to be the major pigeon pea diversity zones in southern Benin. The lowest diversity was recorded in the agro-ecological zone VII with only four (4) known or cultivated landraces and Shannon diversity index estimated at 1.42. In contrast to the zones V and VI, pigeon pea landraces in this last zone were not cultivated in the manner $(\mathrm{D}=0.53$ against 0.73 and 0.77 for the latter respectively)

At village level, Zondrèbohoué in the agro-ecological zone VI presented the highest Shannon diversity index $\left(H^{\prime}=2.59\right)$ and Pielou's evenness $\left(H^{\prime}=0.92\right)$. In this village, the seven local varieties recorded are all cultivated with the same intensity and occupied practically the same proportion $(\mathrm{D}=0.83)$ in the total surface devoted to pigeon pea cultivation. Any variety was found to be neglected or abandoned by the producers in this village. Some villages like Agbédoumè (zone VI), Anakpa, Aclimey, Djikpamè and Dékpo (zone $\mathrm{V}$ ) showed also important diversity indexes ( $\mathrm{H}^{\prime}>$ $2.0)$ and evenness ( $\mathrm{E}>0.7)$. In contrast, Ihoro and Issaba in the agro-ecological zone VII presented the lowest varietal diversity with Shannon indexes of 0.41 and 0.92 and Pielou's evenness of 0.41 and 0.46 , both respectively. Only few 
numbers of landraces were cultivated in these villages. The lowest value of Pielou's evenness observed indicated that the diversity was not evenly distributed. Some landraces, especially those threatened, were not any more cultivated at Ihoro and Issaba.

Table 4: Varietal richness and diversity indexes of pigeon pea in southern Benin

\begin{tabular}{|c|c|c|c|c|c|}
\hline \multirow[b]{2}{*}{ Geographic locations } & \multicolumn{2}{|c|}{ Varietal richness } & \multicolumn{3}{|c|}{ Diversity indexes } \\
\hline & $S$ & $S v$ & $H^{\prime}$ & $\boldsymbol{E}$ & $D$ \\
\hline & & \multicolumn{4}{|c|}{ Agro-ecological zones } \\
\hline Zone V & 7 & 7 & 2.23 & 0.80 & 0.73 \\
\hline Zone VI & 7 & 7 & 2.33 & 0.83 & 0.77 \\
\hline \multirow[t]{2}{*}{ Zone VII } & 4 & 4 & 1.42 & 0.71 & 0.53 \\
\hline & & \multicolumn{4}{|c|}{ Villages } \\
\hline Anakpa & 7 & 7 & 2.07 & 0.74 & 0.69 \\
\hline Aclimey & 7 & 6 & 2.06 & 0.80 & 0.69 \\
\hline Vévi & 7 & 6 & 1.66 & 0.64 & 0.60 \\
\hline Amanvèda & 7 & 5 & 1.45 & 0.62 & 0.49 \\
\hline Morodani & 4 & 3 & 1.33 & 0.84 & 0.56 \\
\hline Idigny & 4 & 3 & 1.34 & 0.85 & 0.56 \\
\hline Djikpamè & 6 & 5 & 2.04 & 0.88 & 0.72 \\
\hline Dékpo & 7 & 6 & 2.00 & 0.77 & 0.70 \\
\hline Hontonmey & 6 & 4 & 1.80 & 0.90 & 0.69 \\
\hline Lagbavé & 7 & 7 & 1.97 & 0.70 & 0.66 \\
\hline Agbédoumè & 7 & 6 & 2.14 & 0.83 & 0.72 \\
\hline Djoudomè & 5 & 4 & 1.03 & 0.51 & 0.43 \\
\hline Zondrèbohoué & 7 & 7 & 2.59 & 0.92 & 0.83 \\
\hline Ganhayadji & 6 & 5 & 1.98 & 0.85 & 0.71 \\
\hline Soglonouhoué & 5 & 3 & 1.32 & 0.83 & 0.54 \\
\hline Lanta & 7 & 3 & 1.49 & 0.94 & 0.62 \\
\hline Tchanvèdji & 7 & 6 & 1.87 & 0.72 & 0.60 \\
\hline Iganan & 3 & 3 & 1.05 & 0.66 & 0.40 \\
\hline Ihoro & 2 & 2 & 0.41 & 0.41 & 0.15 \\
\hline Issaba & 4 & 4 & 0.92 & 0.46 & 0.33 \\
\hline
\end{tabular}

\section{Social factors affecting pigeon pea varietal diversity}

The table 5 presents the descriptive statistics of the distribution of pigeon pea diversity following the categories of social factors considered. In the all ethnic groups surveyed, the number of cultivated landraces was lower than the number of landraces listed or known. Indeed, Agoun and Fon farmers listed the higher number of landraces with in average, $4.66 \pm 0.81$ and $4.31 \pm$ 1.59 landraces respectively. But on the other hand, the higher number of landraces cultivated was recorded in Adja ethnic group with in average $1.32 \pm$ 
0.64 landraces. A lowest varietal diversity was observed in Holli and Nago ethnic groups. The farmers of these ethnic groups cultivated in average $1.29 \pm$ 0.45 landraces while $2.55 \pm 0.86$ and $2.18 \pm 0.56$ landraces listed respectively. In the study area, men and women listed almost the same number of pigeon pea landraces but the women cultivated more landraces than men. The number of landraces cultivated by the women was in average $1.32 \pm 0.58$ against $1.29 \pm 0.54$ landraces for men. In the group of adult farmers, the number of landraces listed was in average $3.25 \pm 1.28$ against $3 \pm 1.12$ and $3.18 \pm 1.28$ landraces cited respectively in young and old farmers' groups. Concerning the number of cultivated landraces, 1.36 \pm 0.62 landraces were recorded in average for adult and 1.34 \pm 0.57 for old farmer groups. Besides, the higher number of landraces cited recorded in the group of producers whose field size was less than 0.5 ha and between 0.5 and 1 ha $(3.15 \pm 1.12$ and $3.37 \pm 1.23$, respectively). In contrast, farmers with field size more than 1 ha cultivated more landraces $(1.46 \pm 0.69)$ although the average number of landraces recorded was lower $(2.91 \pm 1.35)$ than the latter.

Table 5: Distribution of pigeon pea landraces' diversity within farmers' social groups

\begin{tabular}{llcc}
\hline \multirow{2}{*}{ Categories } & Variables & \multicolumn{2}{c}{ Mean values of } \\
\cline { 2 - 4 } & & Diversity cited & Diversity cultivated \\
\hline \multirow{4}{*}{ Ethnic groups } & Adja & $3.13 \pm 0.91^{\mathrm{a}}$ & $1.32 \pm 0.64^{\mathrm{a}}$ \\
& Agoun & $4.66 \pm 0.81^{\mathrm{b}}$ & $1.26 \pm 0.45^{\mathrm{a}}$ \\
& Fon & $4.31 \pm 1.59^{\mathrm{b}}$ & $1.31 \pm 0.51^{\mathrm{a}}$ \\
& Holli & $2.55 \pm 0.86^{\mathrm{c}}$ & $1.29 \pm 0.45^{\mathrm{a}}$ \\
& Nago & $2.18 \pm 0.56^{\mathrm{c}}$ & $1.29 \pm 0.51^{\mathrm{a}}$ \\
\hline \multirow{3}{*}{ Age categories } & Young & $3.00 \pm 1.12^{\mathrm{a}}$ & $1.22 \pm 0.46^{\mathrm{a}}$ \\
& Adult & $3.25 \pm 1.28^{\mathrm{a}}$ & $1.36 \pm 0.62^{\mathrm{a}}$ \\
& Old & $3.18 \pm 1.28^{\mathrm{a}}$ & $1.34 \pm 0.57^{\mathrm{a}}$ \\
\hline \multirow{2}{*}{ Sex } & Men & $3.15 \pm 1.38^{\mathrm{a}}$ & $1.29 \pm 0.54^{\mathrm{a}}$ \\
& Women & $3.13 \pm 1.11^{\mathrm{a}}$ & $1.32 \pm 0.58^{\mathrm{a}}$ \\
\hline & Small & $3.15 \pm 1.12^{\mathrm{a}}$ & $1.19 \pm 0.48^{\mathrm{a}}$ \\
& Middle & $3.37 \pm 1.23^{\mathrm{a}}$ & $1.36 \pm 0.51^{\mathrm{b}}$ \\
& Large & $2.91 \pm 1.35^{\mathrm{a}}$ & $1.46 \pm 0.69^{\mathrm{b}}$ \\
\hline
\end{tabular}

Mean values with the same letter are not significantly different

The effects of social factors on diversity listed and the real diversity planted by the producers were tested through a generalized linear regression analysis followed by an analysis of variance. The results showed that the number of landraces known by farmers was not significantly influenced by their age, sex and field size ( $\mathrm{P}>0.05)$. Indeed, the varietal diversity known by farmers was evenly distributed through age, sex and also field size categories. However, the varietal diversity known by farmers was significantly $(\mathrm{Z}=$ 23.08; $\mathrm{P}<0,001)$ influenced by ethnic group and unevenly distributed through 
the ethnic groups surveyed. In contrast, the varietal diversity maintained or really produced by farmers was significantly influenced by categories of field's size $(Z=4.05 ; P=0.002)$. This was not affected by ethnic group, age categories and sex of farmers.

\section{Traditional management of pigeon pea landraces' diversity}

In all the villages surveyed, farmers did not observe any specific agricultural practices to ensure the varietal purity. In general, the majority of them ( $83 \%$ of respondents) cultivated many landraces together in the same field. Only few producers (17\% of respondents) practiced mono-varietal culture in their fields to maintain the varietal purity. The landraces Projetklui, Wletchive, Kpedevi and Djidjaklui were generally cultivated in mono-varietal culture while the landraces Tchidjahou, Ekluidjoun and Ekluiyou were often cultivated in association with other pigeon pea landraces (Table 6).

Table 6: Agricultural practices in pigeon pea landraces' cultivation in Southern Benin

\begin{tabular}{lcc}
\hline \multicolumn{1}{c}{ Landraces } & \multicolumn{2}{c}{ Cultivation mode (\% of farmers) } \\
\cline { 2 - 3 } & Mono-varietal & Poly-varietal \\
\hline Tchidjahou & 23 & $\mathbf{7 7}$ \\
Ekluidjoun & 43 & $\mathbf{5 7}$ \\
Ekluiyou & 0 & $\mathbf{1 0 0}$ \\
Projetklui & $\mathbf{8 5}$ & $\mathbf{1 5}$ \\
Wletchive & $\mathbf{9 3}$ & 7 \\
Kpedevi & $\mathbf{1 0 0}$ & 0 \\
Djidjaklui & $\mathbf{9 6}$ & 4 \\
\hline
\end{tabular}

Concerning the acquisition of seeds, three different modalities were recorded in the study area. These were self-made, buying and giving systems. In the study area, self-made mode was the system of seed acquisition mainly practiced by the producers. More than $70 \%$ of farmers interviewed therefore retained their grains from the last season for using them as seeds the next season. Buying and giving modes represented respectively $35 \%$ and $23 \%$ of responses rate in the study area. Nevertheless, this trend was not observed in all ethnic groups. For instance, in the Fon ethnic group the producers acquired their seeds more by buying than self-made while in the Agoun ethnic group, producers mostly acquired their seeds by gift (Figure 4). 


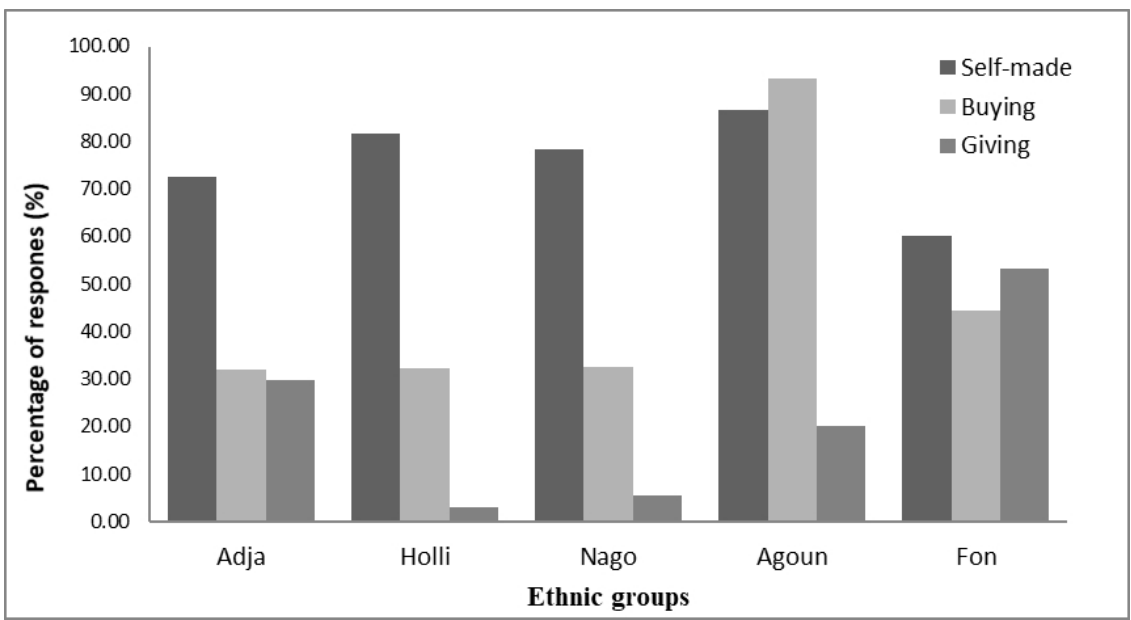

Figure 4: Modes of acquisition of pigeon pea seeds in the different ethnic groups surveyed

\section{Farmers' preference criteria in pigeon pea landrace selection}

Farmers' preference criteria are important for future breeding programs and should be clearly identified. In this study, five preference criteria with variable importance (Fig. 6) were used by farmers to adopt pigeon pea landraces. Among the five preference criteria, two (02) were agronomic (grain yield and maturity cycle), two (02) other were culinary attributes (time of cooking and taste) and the one latter was economic (market value). The most important criterion used by the farmers was economic one with $38.91 \%$ of responses. From the agronomic criteria, grain yield and maturity cycle were all both important; they represented respectively $26.96 \%$ and $25.60 \%$ of responses. In contrast, among the culinary criteria, fast cooking was more important (30.38\% of responses) than taste (14\% of responses).

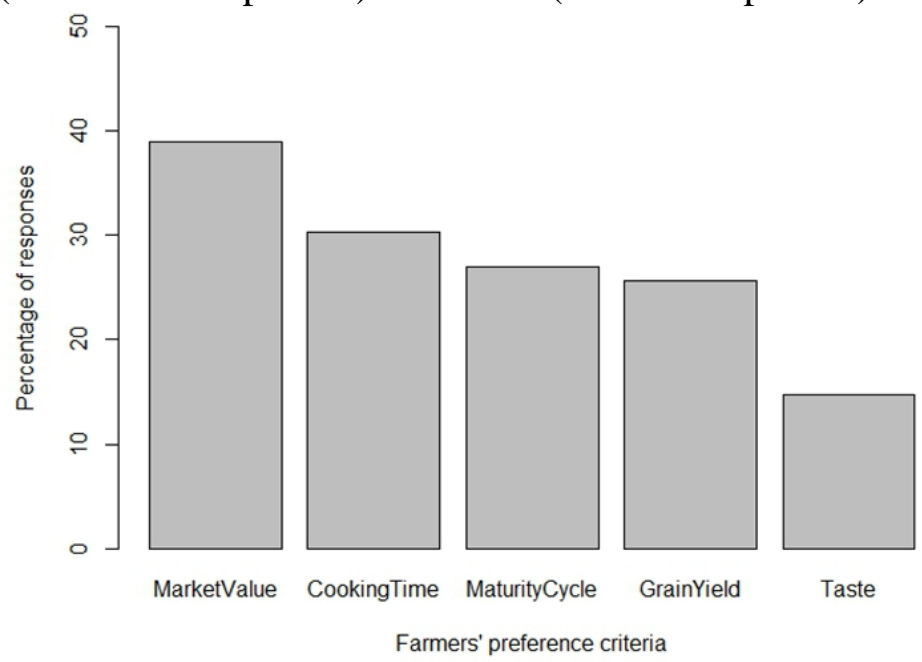

Figure 5: Farmers' preference criteria in pigeon pea landrace selection in southern Benin 


\section{Farmers' preference criteria across ethnic groups}

Farmers' preference criteria varied through the ethnic groups surveyed. The Principal Component Analysis (PCA) of the five (05) farmers' preference criteria yielded three major components among which the first two components displayed an eigenvalue $>1.0$. These first two axis explained $96.45 \%$ of the total variation observed (Table 7). Correlations analysis between farmers' preference criteria and the PC axis showed that the first two components expressed mainly the agronomic criteria and culinary attributes. The first axis was positively correlated with the grain yield and taste while the second axis was positively correlated with maturity cycle and cooking time.

Table 7: Correlation between farmers' preference criteria and the three major principal components

\begin{tabular}{cccc}
\hline & Axis 1 & Axis 2 & Axis 3 \\
\hline Eigenvalues & 3.658 & 1.165 & 0.158 \\
\% of variance & 73.152 & 23.298 & 3.155 \\
Cumulative & 73.152 & 96.45 & 99.605 \\
\hline & \multicolumn{3}{c}{ Scores of criteria } \\
\hline Market value & -0.878 & -0.396 & 0.264 \\
Cooking time & -0.948 & 0.186 & -0.254 \\
Maturity cycle & -0.105 & 0.982 & 0.153 \\
Grain yield & 0.989 & -0.089 & -0.012 \\
Taste & 0.999 & 0.02 & 0.019 \\
\hline
\end{tabular}

The projection of the different ethnic groups surveyed onto the plan formed by the first two principal components (Figure 6) showed that the ethnic group Agoun was positively correlated to these two components while Adja and Fon ethnic groups were positively correlated with the first component and negatively to the second. The ethnic group Holli was clearly separated from Nago ethnic group by the second component. Indeed, Holli ethnic group was positively correlated while Nago ethnic group was negatively correlated to the second axis. Besides, this result showed that the preference criteria of Agoun farmers were grain yield, maturity cycle, taste and fast cooking. In contrast, for Adja and Fon farmers, the main preference criteria were grain yield and taste. The preference criteria in Holli ethnic were maturity cycle and cooking time. The ethnic group Nago was negatively correlated to the two components and the preference criteria of farmers were not agronomic but economic as they attached a particular importance to the market value. 


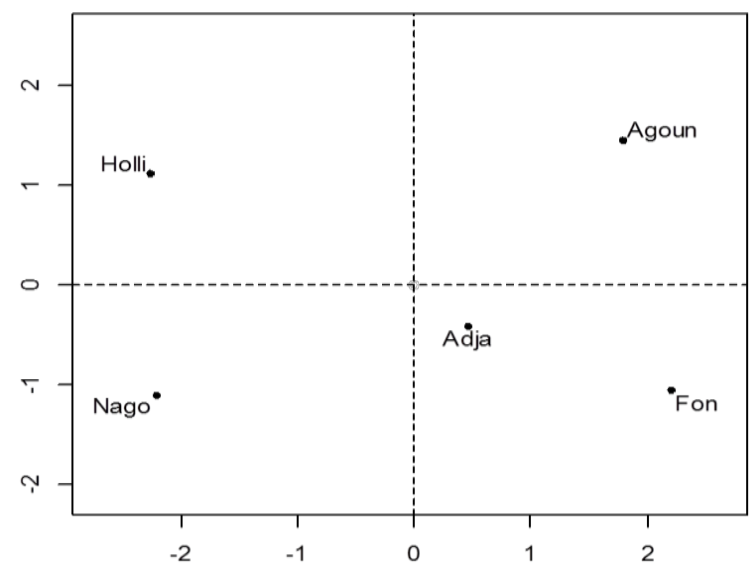

Figure 6: Projection of the different ethnic groups in the PCA axis system

\section{Link between farmers' preference criteria and local landraces cultivated}

The link between farmers' preference criteria and the local landraces cultivated was revealed by a factorial analysis of correspondence. The eigenvalues extracted from this analysis indicated that the first two principal axis explained $95.94 \%$ of the total variation. The projection of farmers' criteria and pigeon pea landraces cultivated in the system formed by the first two axes (Dim $1 \& 2$ ) defined three groups of landraces characterized by the farmers' preference criteria (Fig. 7). The first group contained the local landraces Projetklui, Ekluiyou, Ekluidjoun, Wletchivé and Kpédévi. These were correlated to the maturity cycle and cooking time. The second group associated market value to the landrace Tchidjahou. Finally, the criteria taste and grain yield were associated to the landrace Djidjaklui and formed therefore the third group.

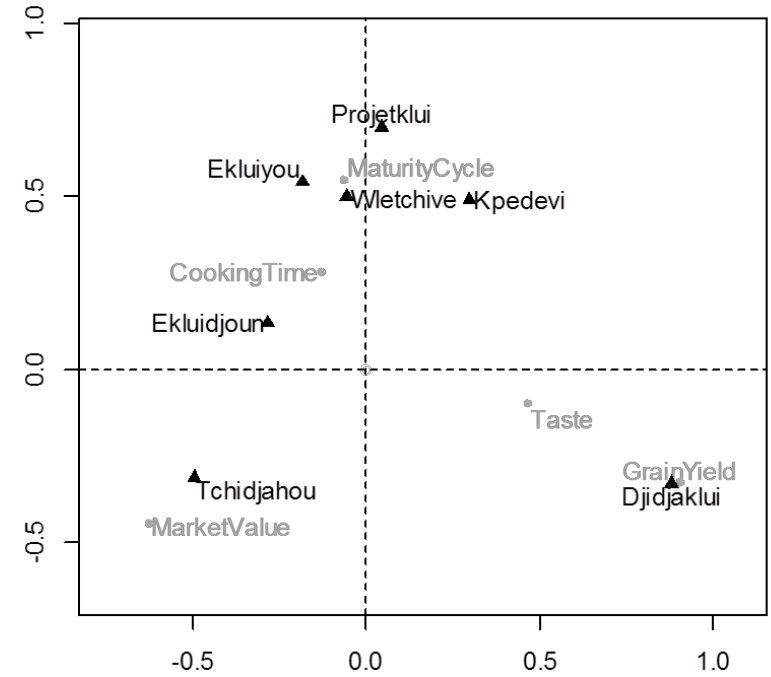

Figure 7: Factorial analysis of correspondence showing the relationship between farmers' preference criteria and pigeon pea landraces cultivated 


\section{Discussion}

In this study, we used quantitative approaches to analyze the organization of pigeon pea landraces diversity and its traditional management in the major producing areas in Southern Benin. The study confirmed the neglected status of pigeon pea crop in Benin with its cultivation, essentially restricted, done by poor farmers often on almost small areas (Dansi et al., 2012). As already reported by Adoukonou-Sagbadja et al., (2006) in fonio millet production in Togo, many reasons were advocated to explain the worrying decline observed in the pigeon pea production in Benin. Among these, the long maturity cycle of many landraces, the low yield and mainly the poor market demand were the main factors which limited the production. Despite its global neglected, pigeon pea is still cultivated in some villages in southern Benin where the farmers maintained in situ the diversity in landraces cultivation. The present study revealed clearly that, in the study area, farmers were highly attached to the crop cultivation that they carefully conserved. This is a good prospect for future valorization actions to promote this important but neglected crop in Benin.

Folk taxonomy or traditional classification of crop landraces is essential as these are the basic units that farmers manage, select and use diversity of their crops (Adoukonou-Sagbadja et al., 2006, Mekbib 2007, Barry et al., 2008). In all the producing zone surveyed, pigeon pea was designed by a generic name which varied through the ethnic groups. In addition to this variability in local generic names, our results showed that the farmers used other criteria in their local taxonomy to design and classify landraces. For instance, pigeon pea landraces were mainly identified and named using the color of seeds. This criterion was well reported in the recent study of Ayena et al., (2017) in pigeon pea as well in local taxonomy of many crops such as fonio millet (Adoukonou-Sagbadja et al., 2006), sorghum (Missihoun et al., 2012), maize (N'da et al., 2013) or Kersting's groundnut (Assogba et al., 2015). Although folk taxonomy is not accurate as formal description based on agro-morphological attributes or molecular markers, it is an important preliminary step to well orient germplasm collection and further researches (Adoukonou-Sagbadja et al., 2006).

In the study area, seven local pigeon pea landraces' in use by local farmers were recorded. Despite this relatively important diversity registered comparably to those reported in other studies elsewhere (Izquierdo et al., 2009, Neelamegan et al., 2015), only few (1.07 to 1.70) landraces were grown per farmer. These observations corroborate those already reported in diverse studies (Adoukonou-Sagbadja et al., 2006, Barry et al. 2008, Labeyrie et al., 2011, Agre et al., 2015, Dossou-Aminon et al., 2016), which revealed that, in general, only a few number of landraces was often cultivated at farmer as well as village level even though more landrace 
diversity exists in crops. This could mainly be explained by farmer preferences in landrace selection that were here found to be correlated to agronomic (maturity cycle, grain yield) and organoleptic (cooking time, taste) attributes as well as market value of pigeon pea landraces.

Social factors, although often neglected in the diversity studies, have nonetheless important impacts on the organization of diversity in crops (Leclerc and Coppens d'Eeckenbrugge 2012, Labeyrie et al., 2013, Missihoun et al., 2012, Diaz-Reviriego et al., 2016). In their study, Ayena et al., (2017) tested the influence of the age of the respondent, the number of years of experience in pigeon pea cultivation, the size of household, the number of family members engaged in agricultural activities and the gender of farmer on the landrace diversity held by household but no significant association $(\mathrm{P}>$ 0.05) was detected. In this study, we considered other four social factors to reinvestigate their possible links with pigeon pea landrace diversity known as well that maintained in-situ. Our results showed that two of the four social factors, i.e. the ethnic group and the farmers' field size, significantly influenced pigeon pea landraces diversity. The significant difference of pigeon pea diversity observed across the ethnic group could be explained by the cultivation history of this crop in some ethnic groups. For example, Adja people in the study area have a very long history in pigeon pea cultivation and this ethnic group was considered in the meantime as the group having more indigenous knowledge on pigeon pea. Additionally, Holli and Nago ethnic groups have also important historical experiences and cultural links with pigeon pea. Indeed, in the last ethnic groups, farmers organize each year a cultural party known as pigeon pea festival. Such traditional festival, depicting solid secular links between a plant and a human community, was also reported in Akposso and Akébou tribal communities for fonio millet (Ovazu) in Central Togo (Adoukonou-Sagbadja et al., 2006). Besides, absence of significant association of age and gender with both type of diversity (known and practiced) at household level supports Ayena et al., (2017) and the previous study by Labeyrie et al., (2013) in sorghum. However, in some other studies it was found that the diversity was function of gender. For instance, women maintained a higher richness of medicinal plants in their home gardens than did men (Diaz-Reviriego et al., 2016).

Traditional management and agricultural practices can also affect the diversity in crops (Missihoun et al., 2012). According to Alvarez et al. (2005), in addition to farmer's preference and selection criteria, traditional seed system and varieties management practices shape the diversity maintained in situ. Pigeon pea producers in the study area acquired their seed by selfproduction. They retain the grain for making them the seeds of next season. This practice, commonly observed in many crops (Adoukonou-Sagbadja et al., 2006, Labeyrie et al., 2011, Missihoun et al., 2012, Assogba et al., 2015), 
enabled farmers to maintain a purity in their planting seed. However, in the present study, some farmers practicing at least two different landraces grew them in the same field and harvest them all together. This can favor gene flow and hampers seed purity since the outcrossing rate in this naturally selfpollinated plant is reported to be high (45\%) (Njung'e et al., 2016).

In this study, five criteria regrouped into three main groups were used by pigeon pea producers to choose and adopt local varieties. In contrast to some previous studies such as those on cassava (Agré et al., 2015) and chili (Orobiyi et al., 2015) in Benin or on yam in Togo (Dansi et al., 2013), the number of criteria used by farmers reported in our study was lower. This could be justified by the fact that pigeon pea is a plant which resists to several biotic and abiotic stresses and well adapted to different agro-ecological and environmental requirements. Besides, farmers' criteria recorded in the study area varied across the ethnic groups. The convergence in the preference criteria between Fon and Adja (grain yield and taste) could be explained by the cultural links and intensive exchange between the two communities. In contrast, the divergence observed between Nago (market value) and Holli (maturity cycle and cooking time) ethnic groups despite their cultural links could be related to the isolated life history of the latter community reducing to the minimal the exchanges with neighbors. These farmer preference criteria are known be important as they may help to orient pigeon pea breeding and to later facilitate the adoption of improved varieties (Adoukonou-Sagbadja et al., 2006).

For efficient conservation strategies, the understanding and identification of geographical zone of diversity and extent of varieties are important (Brown and Marshall 1995, Adoukonou-Sagbadja et al., 2007). In this study, we combined diverse diversity indexes to infer the extent and distribution of pigeon pea landraces diversity in the southern Benin. The high values of diversity observed in agro-ecological zones V and VI (Table 4) indicated that these zones are the major centers of pigeon pea diversity in the southern Benin. These findings are important for future germplasm collection and conservation. For instance, the present study revealed that some villages like Anakpa, Aclimey, Djikpamè and Dékpo in agro-ecological zone V, Agbédoumè and Zondrèbohoué in agro-ecological zone VI maintained the largest diversity. These villages can serve as pilot sites for implementing in situ conservation programs. Besides, among the three groups of landraces identified, two landraces were found to be rare and their production highly neglected by the farmers. The first explanation of the trend observed in these rare landraces could be the introduction and adoption of new improved varieties by farmers. Another possible reason for the abandonment of these rare landraces reported was that their consumption would give vertigo. Urgent 
ex-situ as well in situ conservation actions are therefore required to preserve these landraces against genetic erosion.

\section{Conclusion}

This study confirmed the neglected status of pigeon pea in Benin and showed that the varieties cultivated by farmers are still local landraces with long cycle maturity and low grain yield. But, despite its status, almost great pigeon pea diversity was cultivated by the farmers. The pigeon pea landrace diversity is unequally distributed and varied across the villages and agroecological zones in the study area. Our results show that two social parameters (ethnic group and field size) have an impact on the spatial distribution of pigeon pea diversity. This study provided the opportunity to identify farmer's preferences in selecting a specific variety. Five criteria were mostly used by the farmers to choose their landraces and they vary throughout across the different ethnic groups of the study area. We therefore recommend that future breeding programs take into account of these farmers' preferences. Finally, for efficiently conservation and utilization of pigeon pea genetic resources in Benin, it will be necessary to sample and establish a pigeon pea germplasm collection and conduct agro-morphological evaluation and molecular genetic characterization.

\section{Acknowledgements}

The authors sincerely acknowledge farmers who accepted to share with us their knowledge in pigeon pea cultivation. They are also indebted to Biopaix Ahoyo, Hermann Dossa and Fabienne Adigoun of the Laboratory of Genetic Resources and Molecular Breeding (LaREGAME) and all others who helped during field survey. The study was partially financed through a PhD scholarship grant to the first author by the Beninese Ministry of Higher Education.

\section{References:}

1. Adam, S., \& Boko, M., (1993). Le Benin. Les éditions $d u$ Flamboyant/EDICEF, Cotonou, République du Bénin, 96 p.

2. Adoukonou-Sagbadja, H., Dansi, A., Vodouhè, R. \& Akpagana, K. (2006) Indigenous knowledge and traditional conservation of fonio millet (Digitaria exillis Stapf, Digitaria iburua Stapf) in Togo. Biodiversity and Conservation 15: 2379-2395.

3. Adoukonou-Sagbadja, H., Wagner, C., Dansi, A., Ahlemeyer, J., Daïnou, O., Akpagana, K., Ordon, F., \& Friedt, W. (2007). Genetic diversity and population differentiation of traditional fonio millet (Digitaria spp.) landraces from different agro-ecological zones of west Africa. Theoretical and Applied Genetic 115: 917-931 
4. Agré, A., P., Bhattacharjee, R., Dansi, A., Becerra Lopez-Lavalle, L., A., Dansi, M., \& Sanni, A. (2015). Assessment of cassava (Manihot esculenta Crantz) diversity, loss of landraces and farmers' preference criteria in southern Benin using farmers' participatory approach. Genetic Resources and Crop Evolution 62: 0925-9864

5. Akoegninou, A., van der Burg, W., J., \& van der Maesen, L., J., G. (eds) (2006) Flore analytique de Benin. Backhuys Publishers, Leiden, $1034 \mathrm{p}$

6. Alvarez, N., Garine, E., Khasah, C., Dounias, E., Hossaert-McKey, M., \& McKey, D. (2005). Farmers' practices, meta-population dynamics, and conservation of agricultural biodiversity on-farm: a case study of sorghum among the Duupa in sub-Sahelian Cameroon. Biological Conservation 121: 533-543.

7. Assogba, P., Ewedje, E-E., B., K., Dansi, A., Loko, Y., L., Adjatin, A., Dansi, M., \& Sanni, A. (2015). Indigenous knowledge and agromorphological evaluation of the minor crop Kersting's groundnut (Macrotyloma geocarpum (Harms) Marechal et Baudet) cultivars of Benin. Genetic Resources and Crop Evolution 62: 513 - 529

8. Ayenan, M., A., T., Danquah, A., Ahoton, L., E., \& Ofri, K. (2017). Utilization and farmers' knowledge on pigeonpea diversity in Benin, West Africa. Journal of Ethnobiology and Ethnomedicine 13p. DOI 10.1186/s13002-017-0164-9

9. Barry, M., B., Diagne, A., Pham, J-L., \& Ahmadi, N. (2008). Evolution récente de la diversité génétique des riz cultivés (Oryza sativa et $O$. glaberrima) en Guinée. Cahiers Agricultures 17(2) :122-127.

10. Brown, A., H., D., \& Marshall D., R. (1995). A basic sampling strategy: theory and practice. In: Guarino L, Ramanatha Rao V, Reid $\mathrm{R}$ (eds) Collecting plant genetic diversity, technical guidelines. $C A B$ International, Wallingford, pp 75-91

11. Brush, S., B. (2004). Farmers' Bounty: Locating Crop Diversity in the Contemporary World. Yale University Press, New Haven, Connecticut

12. Dansi, A., Vodouhè, R., Azokpota, P., Yedomonhan, H., Assogba, P., Adjatin, A., Y., L., Loko, I., Dossou-Aminon, I., \& Akpagana, K. (2012). Diversity of the neglected and underutilized crop species of importance in Benin. The Scientific World Journal, Article ID 932947: $1-19$

13. Dansi, A., Dantsey-Barry, H., Dossou-Aminon, I., N'Kpenu, E., K., Agré, A., P., Sunu, Y., D., Kombaté, K., Loko, Y., L., Dansi, M., Assogba, P., \& Vodouhè, R. (2013) Varietal diversity and genetic erosion of cultivated yams (Dioscorea cayenensis Poir - D. rotundata 
Lam complex and D. alata L.) in Togo. International Journal of Biodiversity and Conservation 5(4) 223-239

14. Díaz-Reviriego, I., González-Segura, L., Fernández-Llamazares, Á., Howard, P., L., Molina, J., \& Reyes-García, V. (2016). Social organization influences the exchange and species richness of medicinal plants in Amazonian home gardens. Ecology and Society 21 (1):1.

15. Diwakar, Poudel, Bhuwon, Sthapit, \& Pratap, Shrestha. (2015). An analysis of social seed network and its contribution to on-farm conservation of crop genetic diversity in Nepal. International Journal of Biodiversity, Article ID 312621, $13 \mathrm{p}$

16. Dossou-Aminon, I., Dansi, A., Ahissou, H., Cisse, N., Vodouhe, R., \& Sanni, A. (2016) Climate variability and status of the production and diversity of sorghum (Sorghum bicolor (L.) Moench) in the arid zone of northwest Benin Genetic Resources and Crop Evolution 63:11811201

17. Dury, S., Vallaud, M., \& Coulibaly, H. (2011) Market access of smallscale farms and biodiversity management of food crops. The case of sorghum and pearl millet in Mali. Communication présentée aux 5èmes journées de Recherches en sciences sociales SFER INRA CIRAD. (www.sfer.fr/les colloques2)

18. Greilhuber, J., \& Obermayer, R. (1998). Genome size variation in Cajanus cajan (Fabaceae): a reconsideration. Plant Systematics and Evolution 212: 135-141.

19. Gruère, G., P., Giuliani, A., \& Smale, M. (2009). Marketing underutilized plant species for the benefit of the poor: a conceptual framework. In Kontoleon A, Pasqual $\mathrm{U}$ and Smale $\mathrm{M}$ (Eds.). Agrobiodiversity Conservation and Economic Development. Routledge, Abingdon, UK: 73-87.

20. Guarino, L., \& Lobell, D., B. (2011) A walk on the wild side. Nature Climate Change 1: 374-375.

21. Houehanou, T., D., Assogbadjo, A., E., Glele Kakaï, R., Houinato, M., \& Sinsin, B. (2011) Valuation of local preferred uses and traditional ecological knowledge in relation to three multipurpose tree species in Benin (West Africa). Forest Policy and Economics 13: 554-562

22. IPGRI (2002) Neglected and Underutilized Plant Species: Strategic Action Plan of the International Plant Genetic Resources Institute. International Plant Genetic Resources Institute, Rome, Italy.

23. INSAE : Institut National de la Statistique et de l'Analyse Economique (2015). Production agricole 2008-2012. Retrieved from http://www.insae-bj. org/indice-prix-agricoles.html?file=files/statseconomiques/agriculture/ Production\%20Agricole\%2020082012.xlsx. 
24. Izquierdo, J., Blanco-Moreno, J., M., Chamorro, L., \& GonzalezAndujar, J., L., Sans, F., X. (2009) Spatial distribution of weed diversity within a cereal field. Agronomy for Sustainable Development 29: 491-497

25. Jackson, L., E., Pascual, U., \& Hodgkin, T., (2007) Utilizing and conserving agrobiodiversity in agricultural landscapes. Agriculture, Ecosystems and Environment 121(3):196-210.

26. Jackson, L., van Noordwijk, M., Bengtsson, J., Foster, W., Lipper, L., Pulleman, M., Said, M., Snaddon, J., \& Vodouhe, R. (2010) Biodiversity and agricultural sustainability: from assessment to adaptive management. Current Opinion in Environmental Sustainability 2:80-87.

27. Kahane, R., Hodgkin, T., Jaenicke, H., Hoogendoorn, C., Hermann, M., Keatinge, J., D., H., Hughes, J., Padulosi, S., \& Looney, N. (2013) Agrobiodiversity for food security, health and income. Agronomy for Sustainable Development 33 (4): 671-693.

28. Keatinge, J., D., H., Ledesma, D., Hughes, D’A., J., \& de la Peña, R. (2009) A strategic look to the future for vegetable research: The World Vegetable Centre and its partners. In: Iiyama K (ed) Global climate change: imperatives for agricultural research in Asia-Pacific, JIRCAS, Tsukuba City, Japan, pp 113-118

29. Kombo, G., R., Dansi, A., Loko, L., Y., Orkwor, G., C., Vodouhe, R., Assogba, P., \& Magema, J., M. (2012) Diversity of cassava (Manihot esculenta Crantz) cultivars and its management in the department of Bouenza in the Republic of Congo. Genetic Resources and Crop Evolution 59(8):1789-1803

30. Labeyrie, V., Leclerc, C., Barnaud, A., \& Kamau, J., I., (2011). Influence des facteurs sociaux sur l'organisation de l'agro-biodiversité dans un milieu semi-aride du Kenya. Cinquièmes Journées en Sciences sociales INRA-SFER-CIRAD Dijon, France

31. Labeyrie, V., Rono, B., \& Leclerc, C. (2013) How social organization shapes crop diversity: An ecological anthropology approach among Tharaka farmers of Mount Kenya. Agriculture and Human Values 31(1):97-107.

32. Leclerc, C., \& Geo Coppens d'Eeckenbrugge (2012). Social Organization of Crop Genetic Diversity. The $\mathrm{G} \times \mathrm{E} \times \mathrm{S}$ Interaction Model. Diversity 4(1) 1-32

33. Mekbib, F. (2007) Infra-specific folk taxonomy in sorghum (Sorghum bicolor (L.) Moench) in Ethiopia: folk nomenclature, classification, and criteria. J Ethnobiol Ethnomed 3(38)

34. Missihoun, A., A., Agbangla, C., Adoukonou-Sagbadja, H., Ahanhanzo, C., \& Vodouhê, R. (2012). Gestion traditionnelle et statut 
des ressources génétiques du sorgho (Sorghum bicolor L. Moench) au Nord-Ouest du Bénin. International Journal of Biological and Chemical Sciences 6: 1003-1018.

35. Missihoun, A., A., Adoukonou-Sagbadja, H., Dagba, R., A., Ahanhanzo, C., \& Agbangla, C. (2012) Impacts des pratiques culturales sur l'organisation génétique des sorghos cultivés par les Lokpa au Nord-Ouest du Bénin révélés par les marqueurs SSRs Journal of Applied Biosciences 60 : 4394-4409

36. Neelamegan, R., Roselin, S., Priyanka, A., A., M., \& Pillai, M., V. (2015) Diversity indices of home garden plants in rural and urban areas in Kanyakumari district, Tamil Nadu, India. Scholars Academic Journal of Biosciences 3(9) : 752 - 761.

37. N'da, H., A., Akanvou, L., \& Kouakou, C., K. (2013) Gestion locale de la diversité variétale du maïs (Zea mays L.) violet par les Tagouana au Centre-Nord de la Côte d'Ivoire. International Journal of Biological and Chemical Sciences 7(5): 2058-2068

38. Njung'e, V., Deshpande, S., Siambi, M., Jones, R., Silim, S., \& De Villiers, S. (2016) SSR genetic diversity assessment of popular pigeon pea varieties in Malawi reveals unique fingerprint. Electronic journal of Biotechnology 21: 65-71

39. Orobiyi, A., Dansi, A., Assogba, P., Loko, L., Y., Dansi, M., Vodouhè, R., Akouègninou, A., \& Sanni, A. (2013) Chili (Capsicum annuum L.) in southern Benin: production constraints, varietal diversity, preference criteria and participatory evaluation. International Research Journal of Agricultural Science and Soil Science 3(4). 107120

40. Ortiz, R. (2011) Agrobiodiversity management for climate change. In: Lenné JM, Wood D (eds) Agrobiodiversity management for food security. A critical review. CAB International, Wallingford, p 189-211

41. Padulosi, S., (2011) Unlocking the potential of minor millets. Appropriate Technology 38(1):21-23

42. Pascual, U., Narloch, U., Nordhagen, S., \& Drucker, A., G. (2011) The economics of agrobiodiversity conservation for food security under climate change. Economía Agraria y Recursos Naturales 11: 191-220

43. Perrings, C., Jackson, L., Bawa, K., Brussaard, L., Brush, S., Gavin, T., Papa, R., Pascual, U., \& De Ruiter, P. (2006) Biodiversity in agricultural landscapes: Saving natural capital without losing interest. Conservation Biology 20(2): 263-264

44. Pielou, E., C. (1966) Species diversity and pattern diversity in the study of ecological succession. Journal of Theorical Biology; 10: 370383 
45. R Development Core Team (2014) R: A language and environment for statistical computing. Vienna, Austria: R Foundation for Statistical Computing.

46. Saxena, R., K., Varma Penmetsa, R., Upadhyaya, H., D., Kumar, A., Carrasquilla-Garcia, N., Schlueter, J., A., Farmer, A., Whaley, A., M., Sarma, B., K., May, G., D., Cook, D., R., \& Varshney, R., K. (2012) Large-scale development of cost effective single-nucleotide polymorphism marker assays for genetic mapping in pigeon pea and comparative mapping in legumes. DNA Research. 19(6): 449-461.

47. Seleman, K., Kaoneka, Rachit, K., Saxena, Said, N., Silim, Damaris, A., Odeny, Nadigatla, Rao, Hussein, A., Shimelis, Moses, Siambi, Rajeev, K., \& Rarshney. (2016) Pigeon pea breeding in eastern and southern Africa: challenges and opportunities. Plant Breeding 135: $148-154$

48. Shannon, C., E., \& Waverr, W. (1963) The Mathematical Theory of Communication. University of IIIinois Press: Ur-bana, Illinois.

49. Sharma, S., N., A and Verma, P. (2011) Pigeon pea (Cajanus cajan L.): A Hidden Treasure of Regime Nutrition. Journal of Functional and Environmental Botany 1 (2): 91-101

50. Simpson EH (1949) Measurement of diversity. Nature 163:688.

51. Yabi, I., \& Afouda, F. (2012) Extreme rainfall years in Benin (West Africa). Quaternary International Journal 262:39-43

52. Yenagi, N., B., Handigol, J., A., Bala Ravi, S., Mal, B., \& Padulosi, S. (2010) Nutritional and technological advancements in the promotion of ethnic and novel foods using the genetic diversity of minor millets in India. Indian Journal of Plant and Genetic Resources 23(1) 82-86 